\title{
Enterprise Architecture Planning with TOGAF ADM for Balikpapan College of Economics
}

\author{
Yuyun Tri WIRANTI ${ }^{*}$, Nabila KHAERUNNISA ${ }^{2}$, Lovinta Happy \\ ATRINAWATI ${ }^{3}$, and Vinda DANINGRUM ${ }^{4}$
}

\author{
1,2,3,4 Department of Information System, Kalimantan Institute of Technology, Balikpapan, Indonesia \\ *Corresponding author: yuyun@lecturer.itk.ac.id
}

\begin{abstract}
The information system architecture is a standard reference that later can be used by organizations to develop an integrated information systems. One of the benefits of implementing enterprise architecture is creating harmony between business and information technology for the needs of the organization, besides that information system architecture is also a management practice and technology that is useful to improve company performance by allowing them to see themselves in terms of a holistic and integrated view of strategic direction, business practices, information flows, and technological resources. One of the educational institutions that need information system architecture is Balikpapan College of Economics (STIEPAN). This is because the data and systems owned by STIEPAN have not been well integrated with each other and have not been able to help each activity that runs optimally. For this reason, in this research the architecture of the information system is carried out with the use of The Open Group Architecture Framework (TOGAF) Architecture Development Method (ADM) as a framework. This research produces modeling from business architecture, information system architecture and technology architecture in STIEPAN.
\end{abstract}

Keywords: Architecture, information, STIEPAN

\section{INTRODUCTION}

The problem of quality, timeliness, and change is a condition that forces every organization in all fields globally to face enterprise architecture problems. The things of all the old problems known today define the concept of architecture as the center of the ability to produce quality and timely results and to manage changes in complex processes [1]. Enterprise architecture is the foundation for accommodating the problems that occur in an organization by utilizing technological innovation to meet the expectations of dynamic and ever growing information system architecture. Information system architecture has a framework that later can help align the business needs of the organization and its application to support the vision and mission to be achieved [2].

In the case of education, especially in college, enterprise architecture is also needed in order to improve quality, effectiveness, efficiency, and accountability in the business process. This means that it is required that information technology integrates and supports academic processes and other services provided by the college. The Balikpapan College of Economics (STIEPAN) requires the enterprise architecture to support every academic activity and other services. To model the enterprise architecture, TOGAF was chosen as a framework for resolving architectural problems. The selection of TOGAF is also based on previous research related to information system architecture.
In the first research, it was established that with TOGAF ADM researchers could integrate whatever was needed related to information system architecture that conforms with the institution's vision and mission [3]. In the second research which was also conducted at one of the design high schools in Bali it was found that the existence of information system architecture is useful as a reference for making an integrated system and can also facilitate knowing the system requirements in accordance with the organization [4]. Therefore, to compile information system architecture in STIEPAN, the authors chose to use the TOGAF ADM framework as a solution methodology.

\section{LITERATURE REVIEW ENTERPRISE ARCHITECTURE.}

Enterprise Architecture is a business driven strategy and activity that supports management planning and decision making by providing a coordinated view of all businesses. These views include strategy, business, and technology, which are different from technology based, system level, or process centric approaches. To implement EA it involves core elements, management programs, and framework based documentation methods. In addition, Enterprise Architecture is a management and technology practice devoted to improving company performance by enabling them to see themselves in terms of a holistic and integrated view of strategic direction, business practices, information flows, and technological resources. 
By developing the current and future versions of this integrated view, a company can manage the transition from current operating conditions to the future [5]. Enterprise Architecture produces a blueprint for creating a roadmap for an organization that uses it. So that the organization can implement functions in aligning technology with the company's business processes and making the business value produced more optimal [6]. In addition to other studies, enterprise architecture design can be done to solve the problem that there is no architectural baseline and can produce an architecture blueprint as material to develop an IT master plan as a guide in carrying out IT development [7].

\section{TOGAF FRAMEWORK.}

The Open Group Architecture Framework (TOGAF) is an enterprise information system architecture framework that is quite often used both on a national and international scale. The use of TOGAF has an advantage in terms of aspects provided compared to other frameworks [8]. TOGAF also provides a methodology to develop and implement enterprise architecture, namely Architecture Development Methods [9]. The focus of this research will be phase Architecture Vision, Business Architecture, Information Systems Architecture, Technology Architecture, and Opportunities \& solutions. The TOGAF ADM is the result of continuous contributions from a large number of architecture practitioners. It describes a method for developing and managing the lifecycle of an Enterprise Architecture, and forms the core of the TOGAF standard. It integrates elements of the TOGAF standard described in this document as well as other available architectural assets, to meet the business and IT needs of an organization [10]. The basic structure of the ADM in TOGAF 9.2 is preliminary, architecture vision, business architecture, information system architecture, technology architecture, opportunities and solution, migration planning, implementation governance, architecture change management and requirements management.

\section{RESULTS AND DISCUSSION}

\section{Architecture Vision}

In this phase, the organization's vision and missions are obtained to ensure that the designed business, information systems, and technology architecture are aligned.

\section{Vision.}

To be the excellent business and entrepreneurship development center in Balikpapan.

\section{Mission.}

The first, organizing economics educational programs and learning activities at the undergraduate level in accordance with national standards of higher education based on case studies and entrepreneurship. The second, conducting research activities relevant with the education curriculum and professional development in economics and entrepreneurships in Balikpapan. The third, conducting community service activities to support economic development of Balikpapan. The fourth, conducting reliable training and development of entrepreneurial practices that have global insight for the community and business in Balikpapan. And the last, developing human resources that support the independence and quality of STIEPAN.

\section{Business Architecture.}

There are 7 main business processes at STIEPAN and each represents an organizational unit of STIEPAN, namely the Quality Assurance Unit (UPM), Student Academic Administration Department, Finance Department, Administration Department, Student Affairs Department, Public Relations Department and Study Programs Department, which can be seen in Figure 1

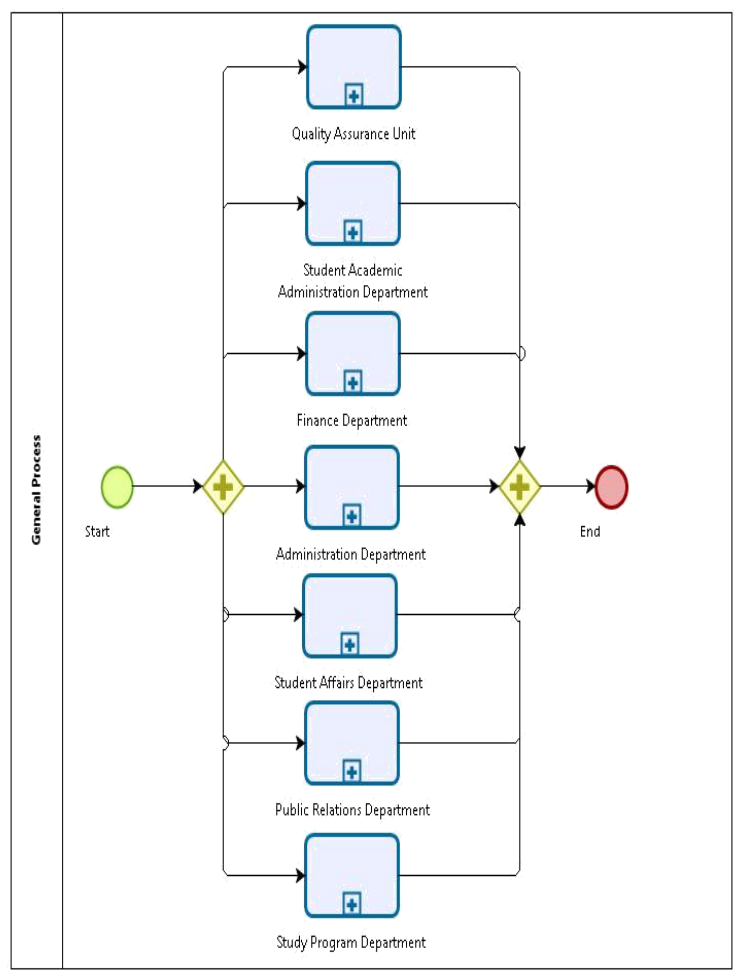

Figure 1 STIEPAN Main Business Process

The first process is Quality Assurance Unit, this unit required to plan, execute, evaluate, monitor, and control the quality of academic activities as well as the budget. 
The Academic Administration Department is responsible to manage operational plans, human resources, facilities, academic calendars, curriculum, student admissions, student data, teaching and learning activities, graduation, alumni, evaluate academic quality and prepare academic reports. The Finance Department tasks are including budget management activities, staffing, implementing budget management activities, managing equipment and investment in goods, managing data and preparing activity reports. The Administration Department has the task of managing and filing incoming and outgoing letters, managing inventory data and preparing activity reports. The Student Affairs Department has the task of coaching planning and student welfare services, implementing coaching and student welfare services, conducting business development of student reasoning power, conducting research and community service, notifying and guiding competition information or work or internships and preparing activity reports. The Public Relations Department has the task of planning collaborative relationships with relevant in the field of research and community service, carrying out collaborative relationships with relevant institutions, organizing public relations and preparing activity reports. And the last is Study Program Department has the task of translating high school vision and mission into the vision and mission of the study program based on the competencies to be achieved, refining and reviewing the curriculum in accordance with the vision and mission and the needs of stakeholders, compiling the academic calendar under the coordination of the chairman of the academic field, preparation of the Learning Implementation Plan and Semester Learning Plan, implementation of teaching and learning activities, program preparation and midterm, final semester examinations, remedial, program preparation and implementation thesis proposal and final examination seminar as well as internships, evaluating the implementation of education and teaching activities in order to fulfill national education standards and preparation of activity reports.

\section{INFORMATION SYSTEM ARCHITECTURE}

\section{Data Architecture.}

The data architecture defines the main data types (data entities) used by each business process. Data entities can be seen in Table

Table 1 Data Architecture

\begin{tabular}{|c|c|}
\hline $\begin{array}{l}\text { Business } \\
\text { Function }\end{array}$ & Data Entity \\
\hline \multirow{7}{*}{$\begin{array}{l}\text { Facilities and } \\
\text { Infrastructure } \\
\text { Management }\end{array}$} & Standard bidding document \\
\hline & $\begin{array}{l}\text { General plan for procurement of } \\
\text { facilities and infrastructure, }\end{array}$ \\
\hline & Data on procurement of goods, \\
\hline & Equipment data, \\
\hline & Special allocation data, \\
\hline & $\begin{array}{l}\text { Accountability report for the } \\
\text { procurement of facilities and } \\
\text { infrastructure, }\end{array}$ \\
\hline & Loan facilities and infrastructure. \\
\hline \multirow{7}{*}{$\begin{array}{c}\text { Student } \\
\text { Admissions }\end{array}$} & New student admission schedule \\
\hline & File written test and interview \\
\hline & New student registration form \\
\hline & File requirements \\
\hline & Prospective new students \\
\hline & College student \\
\hline & Details of new student payments \\
\hline
\end{tabular}




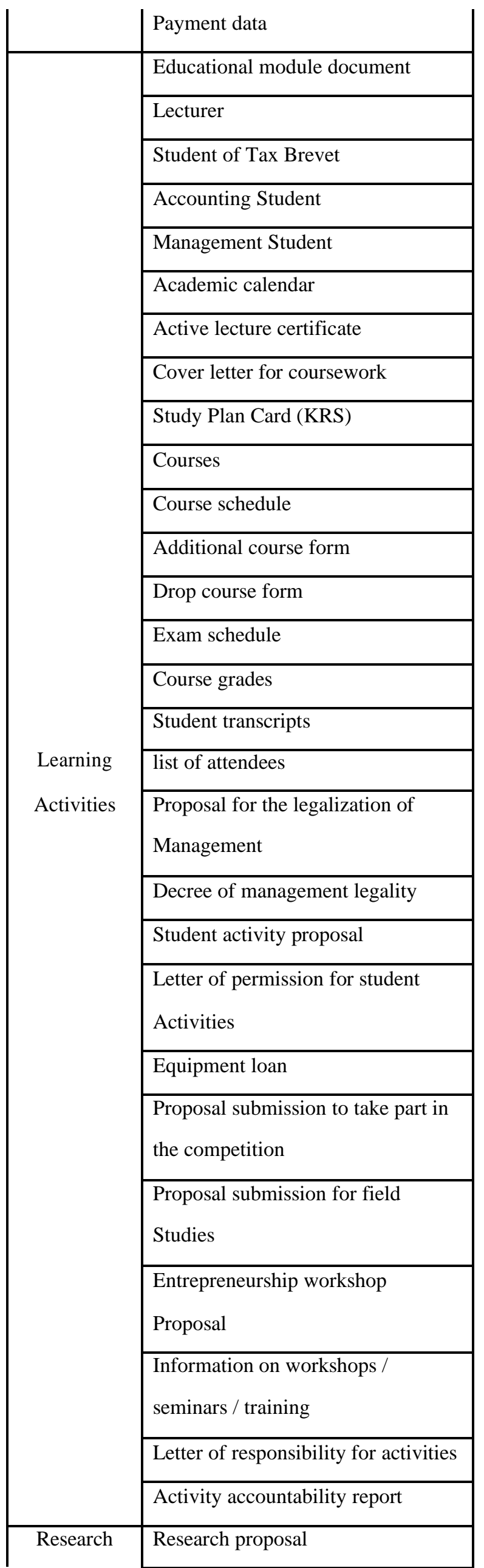




\begin{tabular}{|l|l|} 
and & Community service proposal \\
\hline
\end{tabular}

\begin{tabular}{|c|c|}
\hline $\begin{array}{l}\text { Business } \\
\text { Function }\end{array}$ & Data Entity \\
\hline \multirow{10}{*}{$\begin{array}{l}\text { Community } \\
\text { Service }\end{array}$} & Research permit \\
\hline & Community service permit \\
\hline & Research module \\
\hline & Research report \\
\hline & Community service report \\
\hline & Research result \\
\hline & Community service results \\
\hline & $\begin{array}{l}\text { Information on workshops / } \\
\text { seminars / training }\end{array}$ \\
\hline & Letter of responsibility for activities \\
\hline & Activity accountability report \\
\hline \multirow{11}{*}{$\begin{array}{l}\text { Final Project } \\
\text { Activity }\end{array}$} & $\begin{array}{l}\text { Standard operating procedure for } \\
\text { implementing internships and final } \\
\text { Assignments }\end{array}$ \\
\hline & College student \\
\hline & Supervisor \\
\hline & Examiner \\
\hline & $\begin{array}{l}\text { Internship and final assignment } \\
\text { Schedule }\end{array}$ \\
\hline & $\begin{array}{l}\text { Internship and final assignment } \\
\text { Form }\end{array}$ \\
\hline & Internship submission letter \\
\hline & Final assignment submission letter \\
\hline & Internship report \\
\hline & Final assignment \\
\hline & Alumni data \\
\hline \multirow{4}{*}{$\begin{array}{l}\text { Accreditatio } \\
\text { n Activities }\end{array}$} & ISO 9001:2015 \\
\hline & $\begin{array}{l}\text { Proposed standard operating } \\
\text { Procedure }\end{array}$ \\
\hline & $\begin{array}{l}\text { Document planned activities and } \\
\text { Budget }\end{array}$ \\
\hline & Terms of reference document \\
\hline
\end{tabular}




\begin{tabular}{|l|}
\hline Payment data \\
\hline Administrative planning \\
\hline Planning of PNBP \\
\hline Program and budget evaluation \\
\hline
\end{tabular}

\section{Application architecture.}

The application architecture explains the information system requirements that will be applied at STIEPAN with the aim of defining the applications needed in carrying out business processes at STIEPAN. The application currently being used in supporting the STIEPAN business process can be seen in Table 2.

Table 2 Existing Application

\begin{tabular}{|c|c|}
\hline Information System & Description \\
\hline $\begin{array}{l}\text { STIEPAN's } \\
\text { Website }\end{array}$ & $\begin{array}{l}\text { STEIPAN's Website is a portal for the public to find out information about } \\
\text { STIEPAN. This website is created as a portal for people who want to access } \\
\text { information about STIEPAN without having to go to campus. Developed and } \\
\text { property rights by STIEPAN. You can use this website with online condition. The } \\
\text { website can be accessed if the server and computer are used to access life and } \\
\text { connect to the internet network. There will be development of features from the } \\
\text { STIEPAN's website so that it becomes a website that meets standards and always } \\
\text { presents the latest news related to STIEPAN }\end{array}$ \\
\hline $\begin{array}{l}\text { Academic } \\
\text { Information System }\end{array}$ & $\begin{array}{l}\text { The Academic Information System (AIS) application is useful for managing } \\
\text { STIEPAN academic students. This application is a system standard that must be } \\
\text { owned and used by universities. Developed and property rights by STIEPAN. You } \\
\text { can use this website with online condition. The user who can use this application is } \\
\text { from finance department, academic department, and staff. AIS can be accessed if } \\
\text { the server and computer are used to access and connect to the internet network. AIS }\end{array}$ \\
\hline $\begin{array}{l}\text { Information } \\
\text { System }\end{array}$ & $\begin{array}{l}\text { will be updated as STIEPAN develops in improving the field of } \\
\text { learning so that it will align with the progress of the curriculum and } \\
\text { learning methods in the STIEPAN campus }\end{array}$ \\
\hline
\end{tabular}

In addition to the applications currently used, STIEPAN also has several applications that will be developed and customized to optimize the value that can be generated which can be seen in Table 3 
Table 3 Application to be developed and customized

\begin{tabular}{|c|c|}
\hline Application & Description \\
\hline $\begin{array}{l}\text { Academic Information } \\
\text { System }\end{array}$ & $\begin{array}{l}\text { Manage all process supporting the STIEPAN academic and learning activities. It } \\
\text { manages student data, student's study plan, student's GPA transcript, Lecturer's } \\
\text { achievement index, courses' schedule, and course material }\end{array}$ \\
\hline $\begin{array}{l}\text { Student Information } \\
\text { System }\end{array}$ & $\begin{array}{l}\text { Manage all matters relating to the interests of talent and student activities in } \\
\text { STIEPAN }\end{array}$ \\
\hline $\begin{array}{l}\text { Tracer Study } \\
\text { Information System }\end{array}$ & $\begin{array}{l}\text { Manage all information related to Tracer Study, which is all information about } \\
\text { alumni / STIEPAN graduates to evaluate higher education outcomes }\end{array}$ \\
\hline $\begin{array}{l}\text { Academic Information } \\
\text { System }\end{array}$ & Manage all information related to the Balikpapan academic community. \\
\hline $\begin{array}{l}\text { Infrastructure } \\
\text { Information System }\end{array}$ & Manage all information related to facilities and infrastructure in STIEPAN \\
\hline $\begin{array}{l}\text { Library Information } \\
\text { System }\end{array}$ & Manage STIEPAN library activities \\
\hline $\begin{array}{l}\text { Research and } \\
\text { Community Service } \\
\text { Management } \\
\text { Information System }\end{array}$ & Assist in managing all matters related to the business process of research and service \\
\hline $\begin{array}{l}\text { Financial Information } \\
\text { System }\end{array}$ & Manage expenditure and receipt of funds in accordance with government regulations \\
\hline $\begin{array}{l}\text { Student Admission } \\
\text { Information System }\end{array}$ & $\begin{array}{l}\text { Become a student registration portal during the new school year and new student data } \\
\text { management }\end{array}$ \\
\hline
\end{tabular}

\section{TECHNOLOGY ARCHITECTURE.}

\section{Hardware Configuration}

STIEPAN uses some hardware in operating existing information systems. The hardware currently used by STIEPAN are Server (Dell Optiplex 380), Processor (Intel ${ }^{\circledR}$ Core $^{\mathrm{TM}}$ i3 CPU M 370), RAM (4 GB, 8GB), Storage (49.6 GB - 1 TB), Input Device (Mouse, Keyboard, Scanner), and Output Device (Monitor LCD, Printer (Laser, Ink))

\section{Software Configuration}

Besides hardware, STIEPAN also has software that is used to support the running of STIEPAN applications. The software currently used by STIEPAN are Server (CMS Module), Webserver (Apache Versi 2.2.22, PHP Versi 5.3.10-1, MySQL Versi 5.5.28), Radio server (Ubuntu 12.04.1 LTS), DBMS (My SQL and ORACLE), and Operating System (Windows 7) 


\section{Network Configuration}

The network design implemented on the STIEPAN infrastructure uses a mixed topology between star and bus topologies. Star topology is implemented on all computers connected to a hub or switch with a UTP cable so that the shape of the design looks like a star. The central hub / switch of the network is responsible for controlling data traffic, so if computer 1 wants to send data to computer 4 , data will be sent to the switch and sent directly to the destination computer without passing another computer. This topology is implemented because if there is a computer that has a problem, it can be easily detected, it is easy to add or subtract a computer without disturbing others, and the security level of a data is higher. The bus topology is implemented on both hubs / switches and routers which are neatly arranged like a queue using only one long coaxial cable with several terminals, and at the end of the cable must be terminated byone terminator. This topology is implemented because there are not many cables used and can save installation costs. The description of the network used by STIEPAN can be seen in Figure 2, Figure 3 and Figure 4.

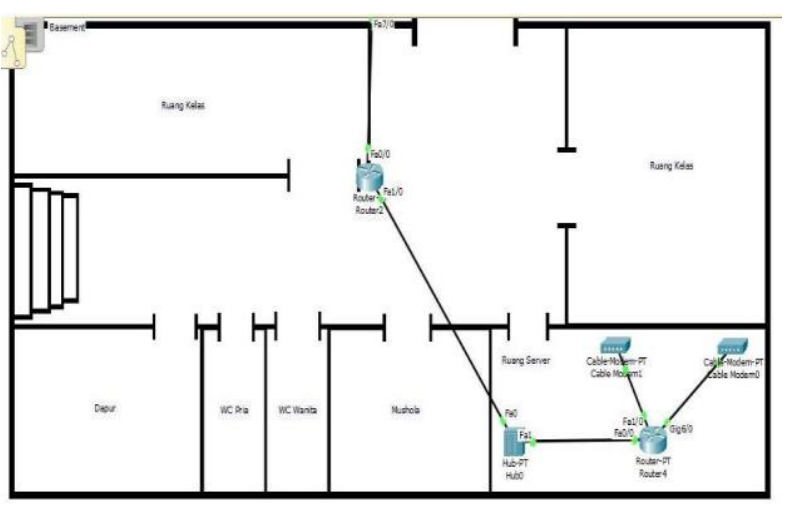

Figure 2 Network on the basement

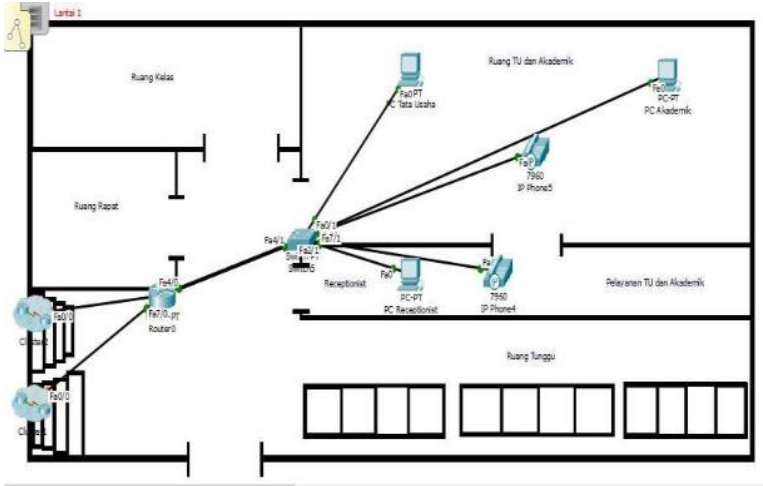

Figure 3 Network on the first floor

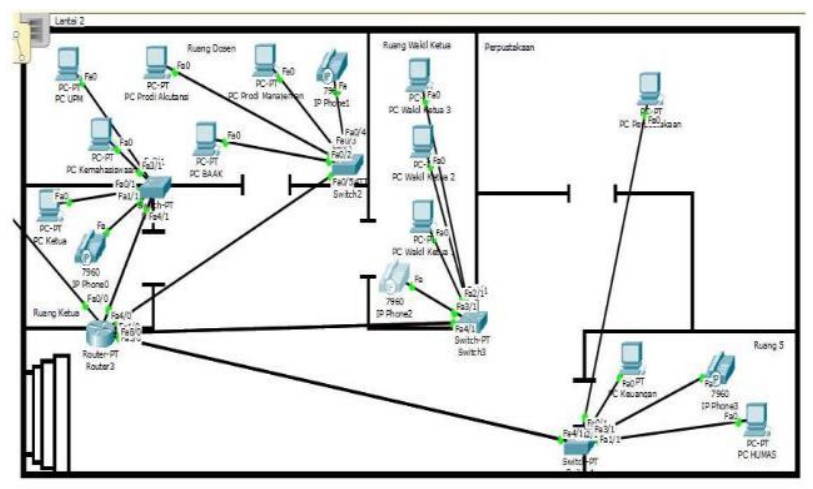

Figure 4 Network on the second floor

\section{OPPORTUNITIES AND SOLUTIONS}

The first stage is priority of application development. At this stage the initial step is to identify the business process that requires support from an information system. There are three application that have the highest priority to be developed based on calculation of demand, risk, potential benefit and operation impact. The priority scale of existing application development can be seen in Table 4 
Table 4 Application development priority value

\begin{tabular}{|c|l|c|c|c|c|c|}
\hline No. & \multicolumn{1}{|c|}{ Information System } & Demand & Risk & $\begin{array}{c}\text { Potential } \\
\text { Benefit }\end{array}$ & $\begin{array}{c}\text { Operation } \\
\text { Impact }\end{array}$ & Value \\
\hline 1. & Infrastructure Information System & 4 & 3 & 4 & 4 & 15 \\
\hline 2. & Research and Community Service & 4 & 1 & 3 & 4 & 15 \\
\hline 3. & Financial Information System & & & & 4 & 15 \\
\hline 4. & Student Admission Information System & 4 & 3 & 4 & 4 & 15 \\
\hline 5. & Website & 4 & 2 & 4 & 4 & 14 \\
\hline 6. & Academic Information System & 4 & 2 & 4 & 4 & 14 \\
\hline 7 & Student Information System & 4 & 2 & 4 & 4 & 14 \\
\hline 8 & Tracer Study Information System & 4 & 1 & 4 & 4 & 13 \\
\hline 9 & Academic Information System & 4 & 1 & 3 & 4 & 12 \\
\hline 10 & Library Information System & 3 & 1 & 3 & 3 & 10 \\
\hline
\end{tabular}

The second stage is scope of information system development. In the scope of information system development is made to determine the features and who are the users involved in the use of operational information systems that can be seen in Table 5. There are several information systems that will be developed laterand several similar software that are open source and commercial that have the same features as the information system proposal needs. 
Table 5 Scope of information system development

\begin{tabular}{|c|c|c|c|}
\hline No & $\begin{array}{l}\text { Information } \\
\text { System }\end{array}$ & Functional Requirement & User \\
\hline 1. & Website & $\begin{array}{l}\text { a. Showing info related to education at STIEPAN } \\
\text { b. Showing info on scholarships for STIEPAN students } \\
\text { c. Showing news about STIEPAN activities } \\
\text { d. Has a contact feature so that new STIEPAN students } \\
\text { can easily find STIEPAN specific info }\end{array}$ & public \\
\hline 2. & $\begin{array}{l}\text { Academic } \\
\text { Information } \\
\text { System }\end{array}$ & $\begin{array}{l}\text { a. Compile student data } \\
\text { b. Schedule courses } \\
\text { c. Arrange courses per semester } \\
\text { d. Fill out the student study plan form } \\
\text { e. Fill in the lecturer achievement index } \\
\text { f. Print transcripts of student's GPA } \\
\text { g. Conduct monitoring and evaluation of lectures } \\
\text { h. Submit a letter related to lectures }\end{array}$ & $\begin{array}{l}\text { Chancellor, Vice Chancellor I, } \\
\text { Student Academic } \\
\text { Administration Department, } \\
\text { Accounting Study Program, } \\
\text { Management Study Program, } \\
\text { Student Affairs Department, } \\
\text { Students }\end{array}$ \\
\hline 3. & $\begin{array}{l}\text { Student } \\
\text { Information } \\
\text { System }\end{array}$ & $\begin{array}{l}\text { a. Make a form for legalizing student organizations } \\
\text { b. Make a proposal for legalization of student } \\
\text { organizations } \\
\text { c. Make a decision letter on student organization legality } \\
\text { d. Make a management legalization form } \\
\text { e. Make a management legalization proposal } \\
\text { f. Make a management legality decree } \\
\text { g. Make a proposal for student activities } \\
\text { h. Make an activity permit letter } \\
\text { i. Make equipment loan } \\
\text { j. Make a competition submission form } \\
\text { k. Make a letter of responsibility for activities } \\
\text { I. Make an activity accountability report }\end{array}$ & $\begin{array}{l}\text { Chancellor, Deputy Chancellor } \\
\text { I, Vice Chancellor III, Student } \\
\text { Affairs Department, Public } \\
\text { Relations Department, } \\
\text { Accounting Study Program, } \\
\text { Management Study Program, } \\
\text { Lecturers, Students, Student } \\
\text { Organizations }\end{array}$ \\
\hline 4. & $\begin{array}{l}\text { Tracer Study } \\
\text { Information } \\
\text { System }\end{array}$ & $\begin{array}{l}\text { a. Providing data on students who have graduated } \\
\text { b. Providing information on experience / work obtained } \\
\text { by alumni } \\
\text { c. Conduct surveys through questionnaires }\end{array}$ & $\begin{array}{l}\text { Students, Student Affairs } \\
\text { Department. Accounting Study } \\
\text { Program, Management Study } \\
\text { Program }\end{array}$ \\
\hline 5. & Academic & a. Providing rector data & Quality Assurance Unit, \\
\hline
\end{tabular}




\begin{tabular}{|c|c|c|c|}
\hline & $\begin{array}{l}\text { Information } \\
\text { System }\end{array}$ & $\begin{array}{l}\text { b. Providing lecturer data } \\
\text { c. Provide data on education staff } \\
\text { d. Make qualified lecturers and students forms } \\
\text { e. Make a letter from outside the academic community }\end{array}$ & $\begin{array}{l}\text { Academic Administration } \\
\text { Department, Student Affairs } \\
\text { Department, Administrative } \\
\text { Department, Accounting Study } \\
\text { Program, Management Study } \\
\text { Program }\end{array}$ \\
\hline 6. & $\begin{array}{l}\text { Infrastructure } \\
\text { Information } \\
\text { System }\end{array}$ & $\begin{array}{l}\text { a. Make standard bidding documents } \\
\text { b. Make a general plan for the procurement of facilities } \\
\text { and infrastructure } \\
\text { c. Make data on procurement of goods } \\
\text { d. Making equipment data } \\
\text { e. Make special allocation data } \\
\text { f. Make a report on the accountability of facilities and }\end{array}$ & $\begin{array}{l}\text { Deputy Chair II, } \\
\text { Administrative Department, } \\
\text { Ministry of Finance }\end{array}$ \\
\hline
\end{tabular}

\begin{tabular}{|c|c|c|c|}
\hline No & $\begin{array}{c}\text { Information } \\
\text { System }\end{array}$ & Functional Requirement & User \\
\hline & & infrastructure & \\
\hline 7. & $\begin{array}{l}\text { Library } \\
\text { Information } \\
\text { System }\end{array}$ & $\begin{array}{l}\text { a. Save book list } \\
\text { b. Keep a list of book shopping needs } \\
\text { c. Save library member list } \\
\text { d. Store and list loan books } \\
\text { e. Save library visit data }\end{array}$ & $\begin{array}{l}\text { Students, Student Affairs } \\
\text { Department }\end{array}$ \\
\hline 8. & $\begin{array}{l}\text { Research and } \\
\text { Community } \\
\text { Service } \\
\text { Management } \\
\text { Information } \\
\text { System }\end{array}$ & $\begin{array}{l}\text { a. Make standard research proposal reports and } \\
\text { community service proposal reports } \\
\text { b. Making standard licensing for research and } \\
\text { community service } \\
\text { c. Publish the research module } \\
\text { d. Collect research reports and community service } \\
\text { reports } \\
\text { e. Providing information on workshops / seminars / } \\
\text { training } \\
\text { f. Collecting accountability for activities } \\
\text { g. Upload activity accountability reports }\end{array}$ & $\begin{array}{l}\text { Students, Public Relation } \\
\text { Departmen, Student } \\
\text { Organizations }\end{array}$ \\
\hline 9. & $\begin{array}{l}\text { Financial } \\
\text { Information } \\
\text { System }\end{array}$ & $\begin{array}{l}\text { a. Make personnel budget documents } \\
\text { b. Make a budget realization document } \\
\text { c. Make operational report documents } \\
\text { d. Make financial report documents }\end{array}$ & $\begin{array}{l}\text { Finance Department, Ministry } \\
\text { of Finance, Staff }\end{array}$ \\
\hline
\end{tabular}




\begin{tabular}{|c|c|c|c|}
\hline & & $\begin{array}{l}\text { e. Make an accountability report document } \\
\text { f. Upload proof of payment } \\
\text { g. Publish bills } \\
\text { h. Publish the template for disbursing funds }\end{array}$ & \\
\hline 10. & $\begin{array}{l}\text { Student } \\
\text { Admission } \\
\text { Information } \\
\text { System }\end{array}$ & $\begin{array}{l}\text { a. Create a registration form for new students } \\
\text { b. Record the data of new students } \\
\text { c. Administering new student registration } \\
\text { d. Publish announcements and registration requirements } \\
\text { e. Publish graduation announcements }\end{array}$ & $\begin{array}{l}\text { New students, Administrative } \\
\text { Department, Academic } \\
\text { Administration Department, } \\
\text { Study Program Department, } \\
\text { Student Affairs Department }\end{array}$ \\
\hline
\end{tabular}




\section{CONCLUSION}

Based on research conducted from the design of the information system architecture at STIEPAN, it can be concluded that the enterprise architecture for STIEPAN has been developed and can be used as a guideline for further information systems development in STIEPAN. Overall, there are 10 applications that needed to be developed in order to fully support the STIEPAN's main business processes, with 4 applications in high priority that are Student Administration Information Systems, Financial Information Systems, Research \& Community Service Information systems, and Infrastructure information systems. In order to implement these information systems, STIEPAN needs to fulfill the technology architecture requirement defined.

\section{ACKNOWLEDGMENT}

This research was financially supported by the Ministry of Research, Technology and Higher Education.

\section{REFERENCES}

[1] R. Yunis und K. Surendro, „Model Enterprise Architecture Untuk Perguruan Tinggi di Indonesia, " Seminar Nasional Informatika 2009, p. 74, 2009.

[2] Suhendri, „Pemodelan Arsitektur Enterprise Menggunakan FrameworkGartner(Studi Kasus : IAINSyekh Nurjati Cirebon),“ Infotech Journal, p. 16, 2016

[3] H. Syahdad, „Perancangan Model Arsitektur Sistem Informasi di Perguruan Tinggi Menggunakan TOGAF ADM (Studi Kasus: Universitas Suryakancana), “ Media Jurnal Informatika, p. 26, 2015.

[4] S. Murpatriwi, A. W. Gustina und I. C. Dewi, „Design of Enterprise Information System with TOGAF Framework

[5] (Case Study: STD Bali),“International Journal of Engineering and Emerging Technology, p. 25, 2016.

[6] S. Bernard, THIRD EDITION of An Introduction to Enterprise Architecture, Bloomington: Author House, 2012.

[7] B. R. F. R. A. und R. Hanafi, „Analysis and Design of Enterprise Architecture PT Unilon Textile Industries on

[8] Human Resource Function (HR) And Procurement Using Togaf ADM,“ Jurnal Rekayasa dan Industri, Bd. V, Nr. 2, 2018.
[9] D. Rahmayanti, R. A. und R. Hanafi, „Analisis dan Perancangan Enterprise Architecture Direktorat Metrologi pada Fungsi Kepegawaian dan Keuangan," Jurnal Rekayasa Sistem \& Industri, Bd. 4, Nr. 1, pp. 106-114, 2017.

[10] R. Pramudita und N. Safitri, „Integrasi Zachman Framework dan TOGAF ADM (Architecture Development Method),“ Information System For Educators and Professionals, p. 159, 2016.

[11]T. O. Group, TOGAF 9.2, San Fransisco: The Open Group, 2018.

[12] G. Davis, „Information System Conceptual Foundations: Looking Backdward and Forward," Information System Conceptual Foundations, p. 67, 2000. 